\title{
SELECTED FACTORS DETERMINING THE PERFORMANCE OF THE CZECH PUBLIC PROCUREMENT SYSTEM
}

\author{
Marketa Sumpikova $^{1}$, Juraj Nemec ${ }^{2}$, Marta Orviska $^{3}$, Matúš Grega ${ }^{4}$
}

\begin{abstract}
Public procurement today represents approximately 15\% of governmental expenditure in developed countries and an area with high potential for continual improvement, especially for countries with transitional economies. This article investigates competitiveness and the selection method, which are two factors of many identified, such as from studies of Transparency International or the Charles University, that relate to the limited results of procurement procedures under Czech Republic conditions. Our study identified important weaknesses in the Czech public procurement process for future reforms to consider.
\end{abstract}

JEL Classification Numbers: H50, H57, DOI: http://dx.doi.org/10.12955/cbup.v3.608

Keywords: public finance, efficiency, effectiveness, competition, public procurement, public procurement law

\section{Introduction}

Since 2008, most European Union (EU) countries have endeavored to reduce public expenditure to stabilize their fiscal imbalances. We consider that there is limited capacity for decreasing expenditure and governments should instead focus on increasing efficiencies and effectiveness of public procurement. Until now, most public procurement studies have focused on the use of electronic auctions, transparency, or corruption in public procurement, with few analyses of competitiveness and selection methods. In our study, we analyze these latter factors and investigate whether increases in efficiency decreases public spending by a significant portion.

\section{Factors influencing performance of public procurement system}

Most governments of the world continue to deal with important fiscal imbalances because of the economic and financial crisis of 2008. Macro-responses have included increasing the International Monetary Fund (IMF) resources and coordinating a monetary policy between central banks and to some extent, a fiscal policy between national governments. Central banks, including the European Central Bank, have engaged in continual interest rate cuts to historically low levels, coupled with a measure called "quantitative easing", which essentially increases money supply through the central bank buying up assets with money it creates. Such assets include government and corporate bonds, with the institutions selling these (often banks) receiving "new" money in their accounts, which subsequently increases money supply.

However, this deficit spending and process of quantitative easing cannot carry on indefinitely and the necessary repayments will mean constrained spending and increased taxes in the following years. This will affect all areas of government spending in every country, and more so in some than others. Currently, this is a mostly hidden problem, as the emphasis has been on avoiding a prolonged economic recession, but several authors, including Dvořák, (2010), have warned of the likelihood of an increasing effect.

Almost all governments involved have and continue to respond by increasing taxes and decreasing expenditure. However, we propose that the focus should involve expenditure, not by lump sum (crosssectional) expenditure cuts, but through improving efficiencies.

\footnotetext{
${ }^{1}$ Marketa Sumpikova, associate professor, Unicorn College, Prague Czech Republic, marketa.sumpikova@unicorncollege.cz

${ }^{2}$ Juraj Nemec, professor, Faculty of Economics and Administration, Masaryk University, Czech Republic, juraj.nemec@econ.muni.cz

${ }^{3}$ Marta Orviska, professor, Faculty of Economics, University of Matej Bel, Slovakia, marta.orviska@umb.sk

${ }^{4}$ Matúš Grega, Faculty of Economics, University of Matej Bel, Slovakia, matus.grega@umb.sk
} 
Public procurement, especially in transitional and post-transitional economies, is generally the major area for improving efficiencies. Many experts (e.g. Pavel, 2013) believe that such improvements will achieve 10-20\% savings in public procurement under our current conditions. Potentially, this releases an amount equal to about 3\% of Gross Domestic Product (GDP) for productive use!

The literature also describes and analyses possible reasons for large inefficiencies in the public procurement processes of the Czech Republic (Pavel, 2013). The common issue in literature is corruption. According to existing data, the general level of corruption in transitional and posttransitional economies is high and unavoidably influences public procurement (Transparency International, 2014). The response of increased transparency does little to help, with it attracting only more sophisticated ways of channeling public resources through procurement.

Literature not only well describes "active corruption" (Rose-Ackerman, 1999), but more and more authors are analyzing "passive corruption". Though this latter concept is relatively new, it has already been investigated under Czech Republic conditions (Pavel, 2013). According to Pavel (2013), passive corruption means wasting public money for no perceived interest, without necessarily being direct corruption . In a later analysis, we deal with two forms of its many dimensions. First is the issue of the "bureaucratic safety” (Nemec, Mikušová Meričková, \& Grega, 2014) and its impact on award criteria. The second is the existence of legislative gaps with a definite negative outcome on the process.

Much literature focuses on competitiveness. Authors like Brannman, Klein, \& Weiss (1987), Gupta (2002), Pavel (2009), Š́́poš \& Klátik (2013) identified competitiveness as a major influence of public procurement. It is difficult to achieve efficiency or quality outcomes, or both, if too few potential suppliers compete for a government contract. For example, Gupta (2002) reported an additional saving of $12-14 \%$ on average with an increase of candidate numbers from two to eight, and after adjusting for extreme values, of 9-10\% on average with an increase of candidate numbers from two to six.

\section{Price as the main selection criterion}

We will assume that excessive bureaucracy in procurement, and a "safety" principle, encourages noncorrupted public officials to use an economics-based selection criterion of the lowest price rather than an efficiency-based one of the best bid. According to the existing literature, as summarized by Pavel (2013), economics should only apply where the procurer can clearly specify the ordered goods, services, or works. There are no general standards, but this equates to the lowest price being a main selection criterion for goods, but less important for services and works.

Figures $1-3$ display our data, which is compiled from the international statistics of selected countries, including the most important central and eastern european countries (CEEC), UK (as example of AngloSaxon "managerialism"), France (as example of different public administration system), and Austria and Germany (as neighbors with Weberian tradition). These are EU Public Procurement statistics (Tenders Electronic Daily, 2014), which clearly show the lowest price criterion as the main principle for selecting suppliers under CEEC conditions. This criterion selection may operate successfully for standardized goods, but not uniformly for services and works. The figures not only show a high percentage of lowest price awards, but also negative trends in the case of the Czech Republic. We argue that bureaucratic decisions of the regulatory body "Úřad pro ochranu hospodářské soutěže" (UHOS) in recent years have caused procurers to opt for safe, but frequently ineffective, decisions. While we had no data for Commonwealth of Independent States (CIS) countries, another study revealed Georgia uses the lowest price as the only available selection criterion for procurement and that a similar situation exists for Russia (Ivanov, 2014). 
CBU INTERNATIONAL CONFERENCE ON INNOVATION, TECHNOLOGY TRANSFER AND EDUCATION MarCh 25-27, 2015, Prague, CZeCh Republic

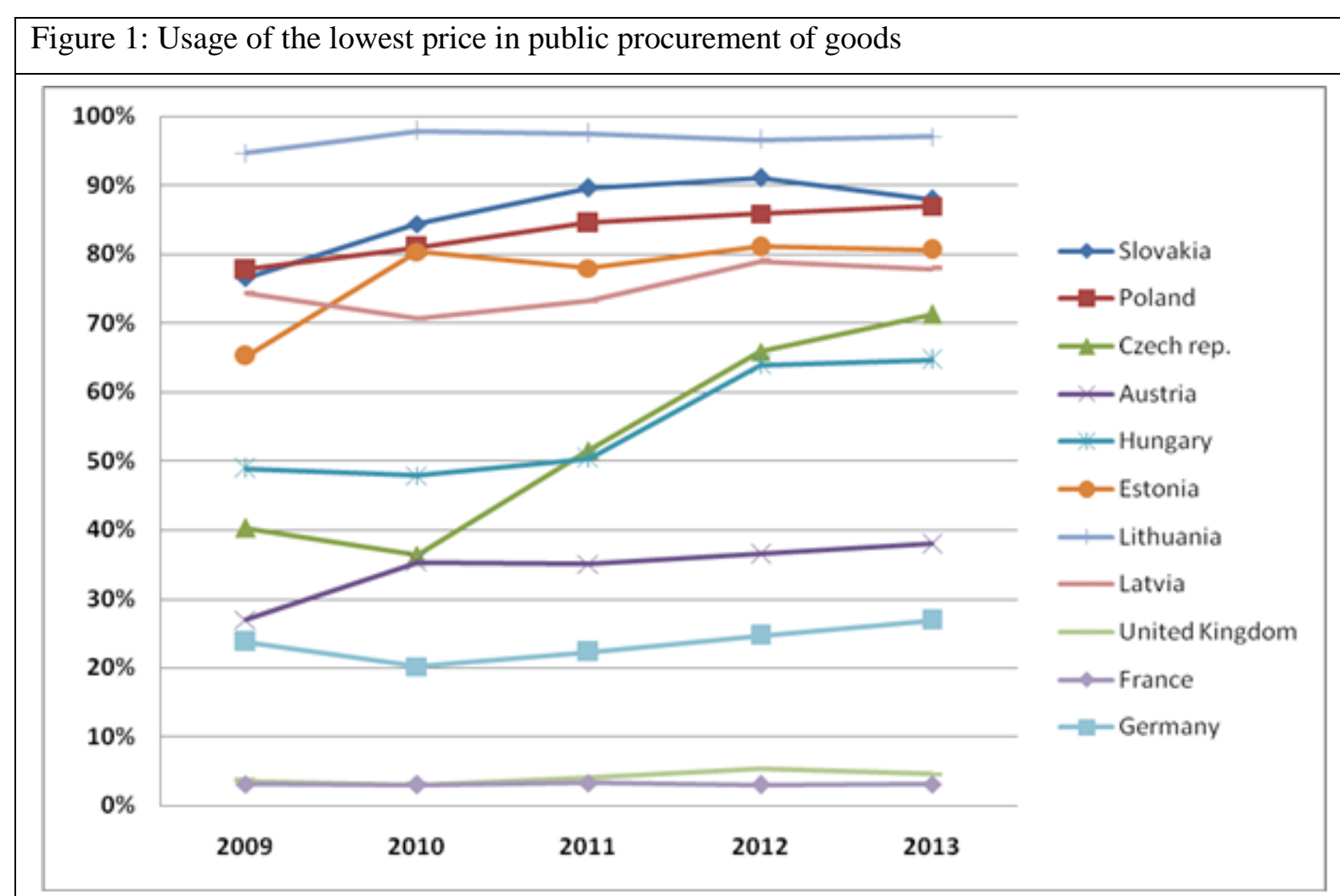

Source: Based on data from Tenders Electronic Daily (2014)

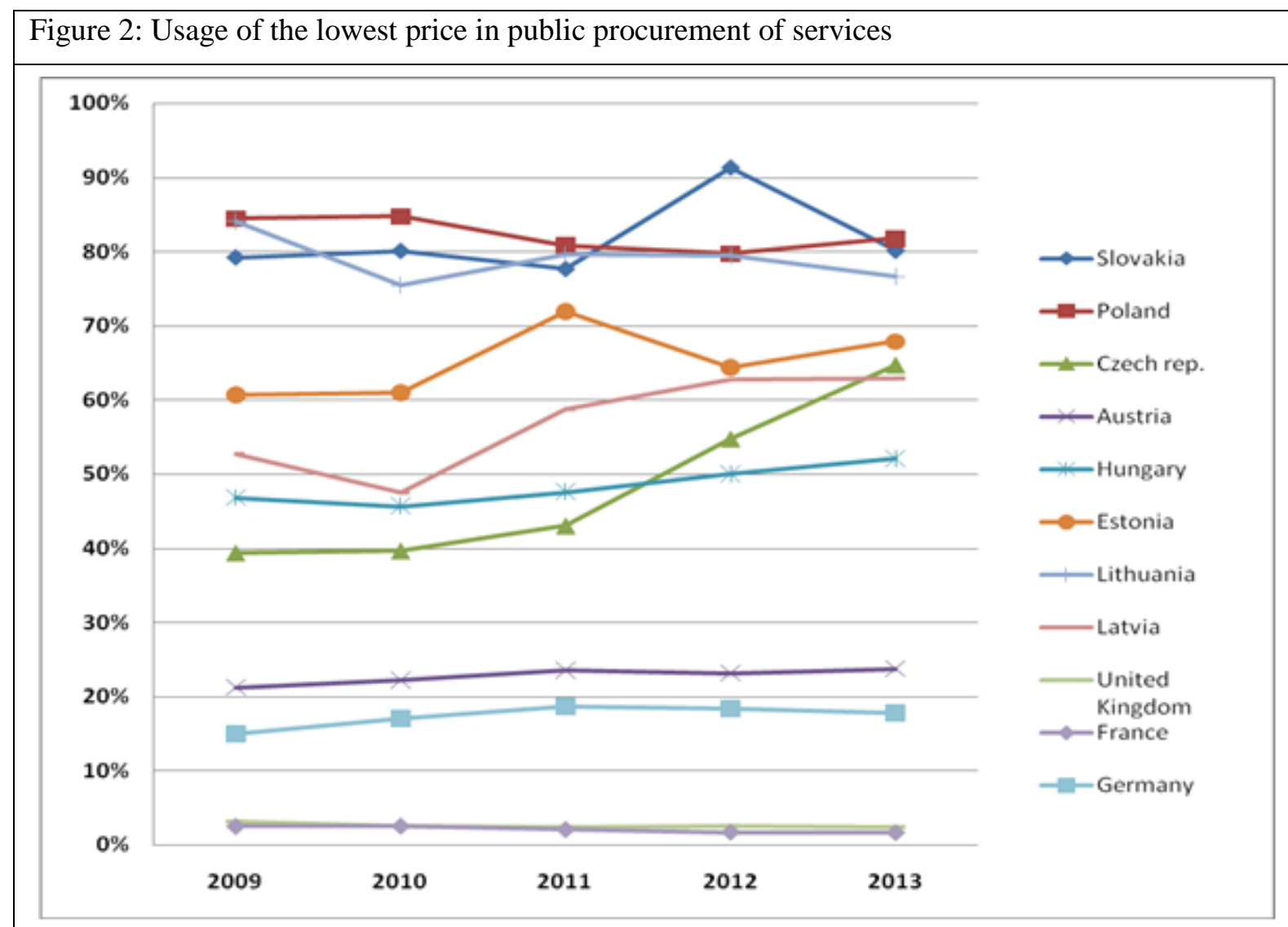

Source: Based on data from Tenders Electronic Daily (2014) 
CBU INTERNATIONAL CONFERENCE ON INNOVATION, TECHNOLOGY TRANSFER AND EDUCATION

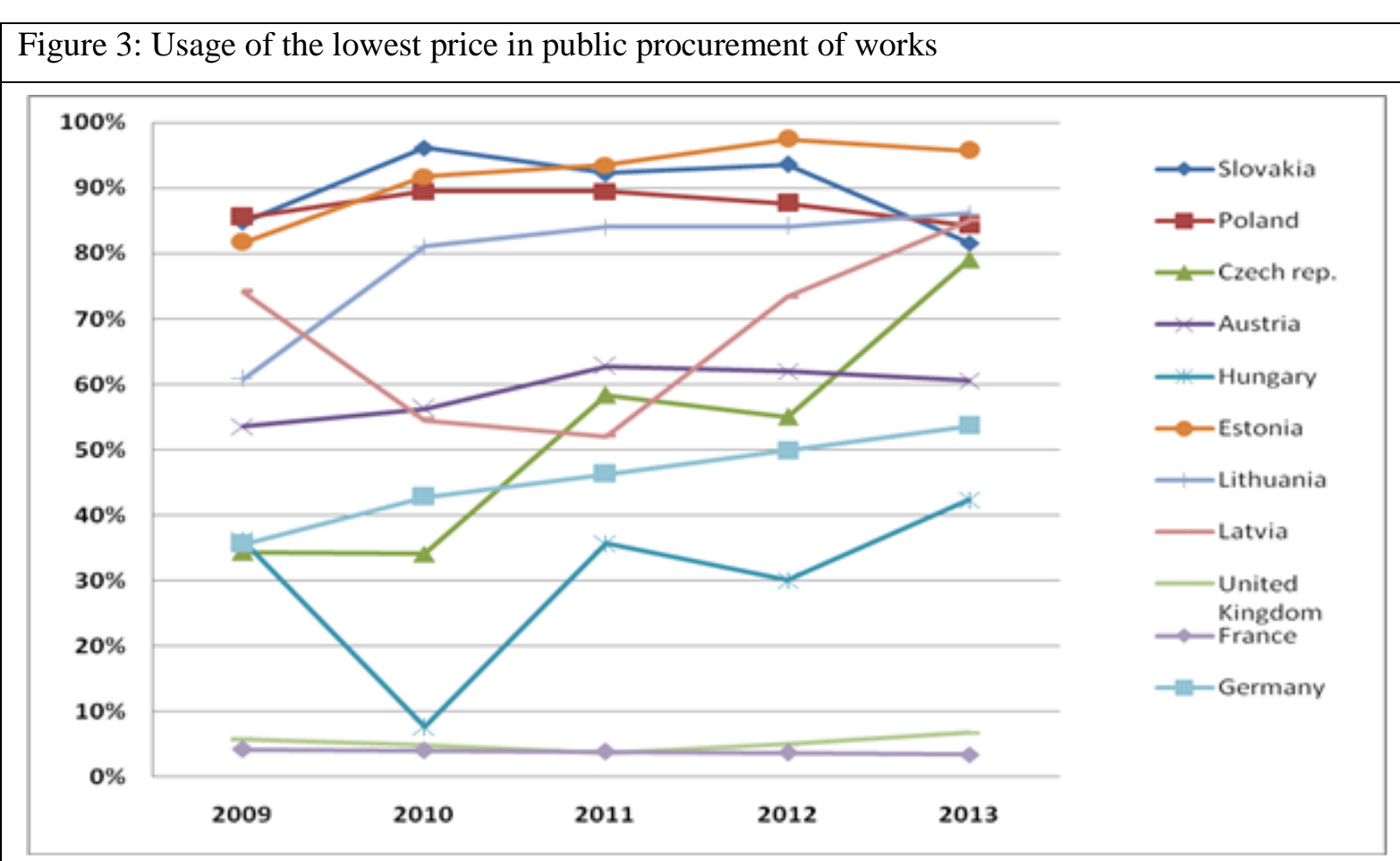

Source: Based on data from Tenders Electronic Daily ( 2014)

\section{Competitiveness}

Czech literature includes an investigation of competitiveness issue. Pavel (2010) analyzed the influence of competitiveness for pricing of road construction and railway infrastructure in the Czech Republic from 2004 to 2009. In his work, Pavel related the estimated contract value to the winning price, and found that on average every other candidate decreased the final price by $3.275 \%$ ceteris paribus. An important finding was the increasing number of offers with decreasing winning price, though the proportion of contracts won by the five largest construction companies did not decrease. The author reports that a stronger competitive environment forced the five strongest companies on the market to lower their prices to maintain their market share and win contracts. In this present paper, we present data from that published annually by the Czech Ministry of Regional Development (Figure 4).

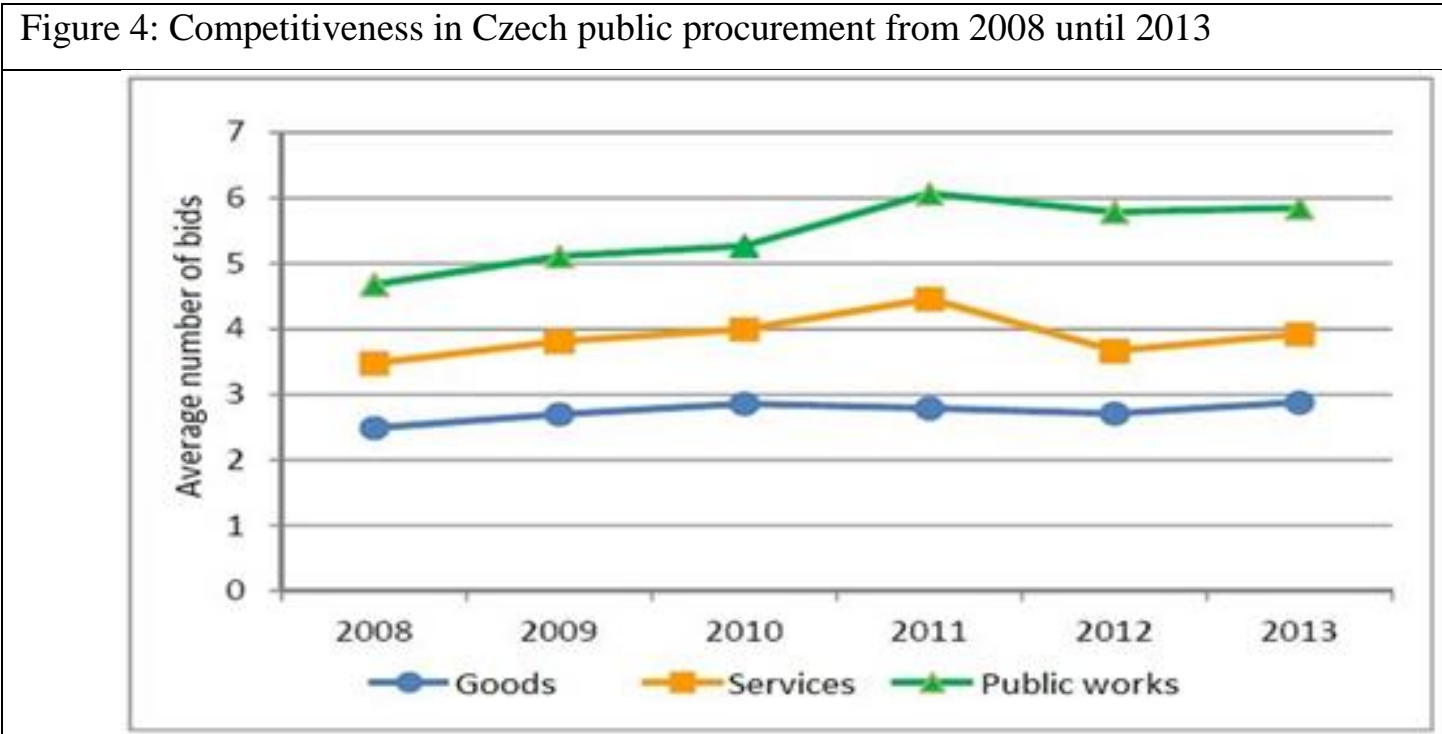

Source: Public procurement annual report for 2013, Ministerstvo pro místní rozvoj ČR (2014) 
Compared to international practice (Figure 5), such level of competitiveness is rather limited (especially for goods) and limits opportunity for better economics and efficiencies.

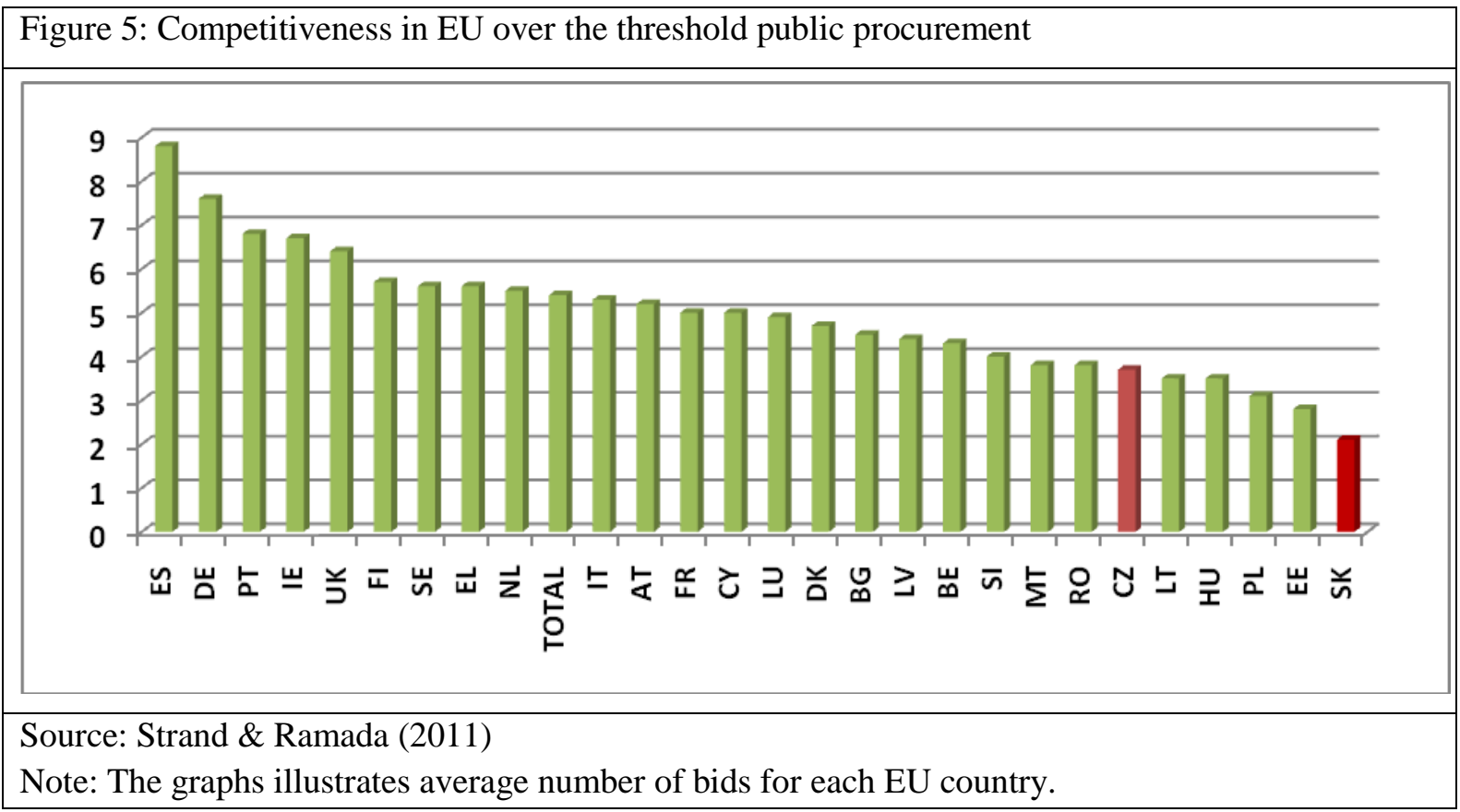

\section{Conclusion}

Our paper argues that the best method of balancing public revenue and expenditure today is to improve efficiency. It provides an important example of an area with potential for large improvement - public procurement. According to our estimates, an amount equal to up to 5\% (or more, with greater pessimism) of GDP is wasted because of allocative and technical inefficiencies in our public sector, and possibly $3 \%$ through ineffective public procurement.

From the many factors determining the success of public procurement, we investigated improper use of price as a selection criterion and competitiveness as a negative effect on the procurement process, and resulting in passive corruption. The data and examples provided clearly show that there is a high capacity for improvement needing additional professional and political attention.

\section{References}

Brannman, L., Klein, J. D., \& Weiss, L. W. (1987). The Price Effects of Increased Competition in Auction Markets. The Review of Economics and Statistics, 69(1), 24-34.

Dvořák, P. (2010). Mimorozpočtové důvody růstu veřejného zadlužení [Non-budgetary reasons the growth of public debt]. Politická ekonomie [Political Economy], 13(4), 522-541.

Gupta, S. (2002). Competition and collusion in a government procurement auction market. Atlantic Economic Journal, 30(1), 13-25.

Ministerstvo pro místní rozvoj ČR [Czech Ministry of Regional Development]. (2014). Public procurement report-Czech republic, 2013 [statistics]. Available from Ministerstvo pro místní rozvoj České republiky.

Nemec, J., Mikušová Meričková, B., \& Grega, M. (2014). Contracting, outsourcing, procurement: Selected factors lifting thein success in the CEE region. In Proceedings of the 18th Annual Conference of the International Research Society for Public Management. Ottawa, Canada.

Pavel, J. (2009). Efektívnost' fungovania kontrolných systémov verejného obstarávania na Slovensku [The efficiency of the control systems of public procurement in Slovakia]. Bratislava, Slovakia: Transparency International.

Pavel, J. (2010). Analýza vlivu míry konkurence na cenu rozsáhlých staveb dopravní infrastruktury [Analysis of competitiveness impact on the final price of transport infrastructure]. Politická ekonómie [Political economics], 14(3), 343356. 
Pavel, J. (2013). Veřejné zakázky a efektivnost [Public procurement and efficiency]. Praha: Ekopress.

Rose-Ackerman, S. (1999). Corruption and government - causes, consequences and reform. Cambridge: Cambridge University Press.

Strand, I., \& Ramada, P. (2011). Public Procurement in Europe: Cost and Effectiveness. [online] Brusel: European Commision, [available online 2014-05-10], 1-128.

Šikula, M. (2010). Stratégia rozvoja slovenskej spoločnosti [Development strategy of the Slovak society]. Bratislava: Ekonomický ústav SAV [Institute of Economic Research].

Šípoš, G., \& Klátik, P. (2013). Kvalita verejného obstarávania na Slovensku v roku 2012 [Quality of public procurement in Slovakia in 2012]. Transparency International Slovensko [online]. Bratislava: Transparency International Slovensko [available online 2014-05-10], 1-5.

Stiglitz, J. E. (1988). Economics of the public sector. New York: W.W. Norton.

Tenders Electronic Daily. (2014). Online database of EU over the threshold procurement - data from 01/01/2009 untill 12/31/2013 [statistics]. Available from TED database, European Commission, http://ted.europa.eu/TED/main/HomePage.do.

Transparency International. (2014). Corruption Perception Index 2014 [statistics]. Accessed http://www.transparency.org/whatwedo/publication/cpi2014 